\section{A MUSEUM FOR INDIA AND THE COLONIES}

$A \mathrm{~T}$ the meeting of the International Congress of A Orientalists in London in 1874 , Dr. Forbes Watson read a paper in which he described (see NATURE, vol. x. p. 4.2I) the plan of an Indian Museum, Library, and Institute. This paper was afterwards published (see NATURE, vol. xi. p. 413). Dr. Watson has just published a pamph!et ${ }^{1}$ in which the proposed India Museum and Institute has very naturally expanded into an Imperial Museum for India and the Colonies. What Dr. Watson proposes is that on the site of the old Fife House, on the Victoria Embankment, at the Thames end of the new Northumberland Avenue, a large and suitable building should be erected, to consist of two divisions, one devoted to the interests and products of India, and the other to those of the various British Colonies. The library and collections which already exist in connection with India are acknowledged to be of great value and importance, and their location in an appropriate building in a central position would greatly increase their usefulness. The arrangement at South Kensington is of course only temporary. Now that Dr. Watson has proposed a plan for an institution which would do for the other colonies what the India Museum and Library attempt to do for India, one wonders why steps have not been taken long ago to supply what appears to be a real want. The subject has, however, engaged for years the attention of those who take an active interest in the Colonies, and several of the Colonies have gone so far as to vote money for the establishment of a Colonial Museum in London. Few people realise the importance of the Colonies to Britain; their extent, population, and the value of their commercial transactions are forcibly exhibited by Dr. Watson in his pamphlet, which we would recommend those to read who wish to have some idea of the value of the Colonies to the mother country. From a scientific point of view such an institution as is proposed would be of great interest and value. British Colonies are to be found everywhere over the surface of the lobe, and embrace all climates and every variety of natural productions. Students of natural science would find a properly arranged collection of our colonial productions of great use, especially if combined with a proper library, and no better method could be devised of educating the public generally as to the extent, importance, physical condition, and natural products of "Greater Britain."

Dr. Watson shows that from every point of view, political, commercial, and scientific, the establishment of such an all-embracing Imperial Institute would be of the greatest benefit both to this country and her Colonies, and would no doubt serve to bind them more closely together. We are sure his scheme needs only to be known in its details to recommend itself to the public, and we are confident that if steps were taken to move the proper quarter, the accomplishment of the scheme would be only a question of time. The Colonies themselves are willing to bear a share of the expense necessary, and it would only be fair that this country, through the Government, should meet the Colonists as far as it can.

Into the details of Dr. Watson's plan we have not space to enter. There would, as we have said, be virtually two museums under one building. In the division devoted to the extra-India Colonies, the museum representative of each Colony would be kept distinct, so that the whole would be rather a federation of museums than one museum. Then there would be a Colonial Library and Reading-room; provision would be made for giving a home in the Institution to the Asiatic Society and the Colonial Institute; by means of "Trade Museums," a full representation would be given of Colonial produce, and in the proposed

x "The Imperial Musenm for India and the Colonies." By J. Forbes Watson, M.D., \& c., Director of the India Museum. (Allen and Co.) institution the offices of the various Colonial agents now dispersed over London could be established. The advan. tages of such an Institution are well summed up by $\mathrm{Dr}$. Watson in the following paragraph :- -

"The combined India and Colonial Museums, estab. lished according to the above plan, would in every way become a living institution worthily representing the past history and the present resources of the British Empire throughout the world. Such an institution would afford not only exhaustive materials for study and research, but would likewise be suitable for reference by the Indian and Colonial authorities, by men of business or of letters, and by officials or emigrants intending to proceed to India or the Colonies. Thus it would be instrumental in furthering actual work or business, whether scientific, political, or commercial. At the same time, through its co-operation with the Asiatic Society and the Colonial Institute, through its reading-room, its lectures and publications, through the Trade Museums and other typical collections distributed all over the country, as well as throughout the most important places in India and the Colonies, all the information would be rendered available to the whole Empire."

\section{FERTILISATION OF FLOWERS BI INSECTS I} XIV.

Flowers Fertilised by the Wings of Butterfies.

$\mathrm{N}$ my former articles many plants are referred to which are fertilised by butterflies, whose proboscis, head, legs, or whole underside comes into contact with the anthers and stigmas of the flowers visited; but hitherto no plant has been known which is fertilised by the fluttering wings of butterflies. My brother, Fritz Müller (Itajahy, Prov. St. Catharina, Brazil), has lately observed a species of Hedychium (Piperaceæ) whose bright red scentless flowers, opening in the morning, are won lerfully adapted to this manner of fertilisation. I give his description, as far as possible, in his own words.

The flowers of this Hedychium are collected in groups of 4-6, which are enveloped by a common bract; in every group only one flower is ever developed at the same time, this commonly fading before the next one has opened. The groups of flowers are arranged in alternating whorls, each consisting of three groups (Fig. 89); the spike thus formed reaches 0.25 metre in length, and is composed of six longitudinal rows of flowers, each row containing about ten.

The corolla-tubes, about $0.03 \mathrm{~m}$. long, 0.5 and I $\mathrm{mm}$. wide, are completely enclosed by the very firm common bract; moreover, each by its calyx closely embracing it, by its special bract and partly by the bracts of the older flowers of the same group. Thus the honey, which on the morning of the first day fills up about one-third, on the morning of the second day about two-thirds of the length of the tube, is excellently protected from being stolen by piercing the tube, of which some Apidæ, especially Hylocopa, are exceedingly fond. The flowers are placed nearly horizontally, the stamen a little above, the lip a little below a horizontal plain intersecting the entrance of the honey-tube. The lip, which in other species of Hedychium is expanded level and almost sessile, is here long stalked, and rolled up into a channel of $0.01 \mathrm{~m}$. in length provided with a funnel-shaped entrance. The entrance of the lip-cliannel (Fig. $89 A$ ) being about equally distant from the two longitudinal rows of anthers and stigmas Fig. $89(B, C)$ between which it is situated, both rows are alike struck by the wings of the butterflies flying on and off.

The filament is $47 \mathrm{~mm}$. Iong on the forenoon of the first day and somewhat bent upwards, so that the pollencovered side of the anther looks outwards or even a little

I Continued from vol. xiii. p. 294. 